\title{
DATE NOI PRIVIND DIVERSITATEA FAUNEI REZERVAȚIEI PEISAGISTICE „DOBRUȘA”
}

\author{
Nistreanu Victoria, Bușmachiu Galina, Țurcan V. \\ Institutul de Zoologie, 2028 Chișinău, R. Moldova \\ vicnistreanu@gmail.com, bushmakiu@yahoo.com
}

https://doi.org/10.53937/9789975315975.17

Rezervația peisagistică Dobrușa este localizată în Raionul Șoldănești, între satele Dobrușa și Olișcani și ocupă o suprafață de 2634,0/ 2736.6 ha. Rezervația include trupul de pădure Drobușa Mică, parcelele 12-29; trupul de pădure Rădi, parcelele 30-32; trupul de pădure Drobușa Mare, parcelele 33-83 (întreprinderea pentru silvicultură Șoldănești, ocolul silvic Olișcani). Altitudinea absolută maximă a rezervației este de 318 m, altitudine minimă $-245 \mathrm{~m}$. Principalele ecosisteme sunt cele forestiere păduri cu predominarea gorunului în amestec cu cu tei și frasin. Studiul diversității specifice al colembolelor și al insectelor din Rezervația peisagistică Dobrușa a fost efectuat în baza materialului colectat în lunile august și noiembrie 2017. Cercetările vertebratelor terestre s-au efectuat pe parcursul mai multor ani.

Collembola. Ca rezultat al cercetărilor efectuate din sol și lemn descompus au fost extrase în total 873 de exemplare de colembole, atribuite la 44 de specii, care făceau parte din 34 de genuri și aparțineau la 13 familii. Cele mai reprezentative din punct de vedere faunistic s-au dovedit a fi familiile Entomobryidae cu un total de 10 specii și Isotomidae - 9, urmate de familiile Hypogastruridae și Neanuridae cu câte 5 specii fiecare, Tullberigae și Onuchyuridae - 3, Tomoceridae și Neelidae - 2. Cinci dintre cele 13 familii identificate și anume Odontellidae, Cyphoderidae, Sminthuridae, Dycirtomidae și Arrhopalitidae au fost prezente în cele 8 eșantioanele colectate doar cu câte o singură specie fiecare și un număr mic de indivizi. Dintre cele mai frecvente specii, care au fost prezente în toate eșantioanele analizate, sunt Protaphorura sakatoi (Yosii, 1966) și 
Parisotoma notabilis (Schaffer, 1896), prima dintre care a înregistrat 210 indivizi, iar cea de-a doua 118 indivizi. Numărul de indivizi ai altor specii a fost cu mult mai mic (1-50 ind.).

Dintre speciile rare în Rezervație putem menționa Thaumanura carolii (Stach, 1920) atestată în Republica Moldova doar în pădurile cu frunza căzătoare ale zonei centrale, prezente în special în rezervațiile Plaiul Fagului, Codrii, Vila Nisporeni și pădurea amplasată lângă localitatea Donici (Bușmachiu, 2016). O altă specie la fel de rară, depistată intr-un număr mic de indivizi în pădurile Moldovei este Superodontella lamellifera (Axelson, 1903), atestată până în prezent în rezervațiile Plaiul Fagului și Codrii. Specia are o distribuție largă în Europa, preferând ecosistemele forestiere și fiind adesea depistată în lemn descompus.

Dintre alte specii de colembole caracteristice ecosistemelor forestiere și prezente în Rezervația peisagistică Dobrușa putem menționa Ceratophysella silvatica RUSEK, 1964, citată până în prezent doar din pădurea de la Rudi (Bușmachiu \& Weiner, 2017). Specia populează litiera pădurilor din zonele montane ale Europei.

Insecta. Conform datelor din literatură în Rezervația peisagistică Dobrușa se întâlnesc următoarele specii de insecte rare: Oryctes nasicornis (Linnaeus, 1758), Lucanus cervus (Linnaeus, 1758), Iphiclides podalirius (Linnaeus, 1758) și Callimorpha quadripunctaria (Poda, 1761) (Andreev et al., 2012). În august 2017, în zona forestieră, au fost văzuți mai mulți bușteni de stejari, rămași în urma defrișării arborilor seculari, fiind în stare avansată de descompunere, în jurul cărora au putut fi observate zeci de insecte moarte de Lucanus cervus de ambele sexe.

Vertebrate terestre. Amfibienii sunt reprezentați de 11 specii (Triturus vulgaris, T. cristatus, Bufo bufo, B. viridis, Bombina bombina, Rana ridibunda, R. lessonae, R. temporaria, R. dalmatina, Hyla arborea și Pelobates fuscus). Fauna de reptile include 6 specii (Emys orbicularis, Anguis fragilis, Lacerta viridis, Natrix natrix, Coronella austriaca și Vipera berus).

Conform datelor existente avifauna este reprezentată de 81 specii clocitoare, 1 
specie oaspete de vară și 4 specii care iernează (Andreev et al., 2012). Ornitofauna este reprezentată de păsări de pradă (Accipiter gentilis, Accipiter nisus, Buteo buteo, Falco tinnunculus, Asio otus, Athene noctua), piciforme (Jynx torquilla, Picus canus, Dendrocopos major, D. syriacus, D. minor, D. medius), paseriforme (Galerida cristata, Lullula arborea, Luscinia luscinia, Turdus merula, T. philomelos, Silvia borin, S. communis, S. articapilla, Muscicapa striata, Parus caeruleus, P. major, Sitta europaea, Oriolus oriolus, Lanius collurio, Troglodytes troglodytes, Carduelis carduelis, Coccothraustes coccothraustes, Oenanthe oenanthe, Alauda arvensis, Motacilla alba, Hirundo rustica, Passer domesticus, Passer montanus, Corvus corax, Corvus cornix, Pica pica, Garrulus glandarius, etc.) și alte specii.

Fauna de mamifere este bogată și include cca 40 de specii, dintre care 6 specii de insectivore, 9 specii de chiroptere, 17 specii de rozătoare, iepurele de câmp, 8 specii de carnivore, căpriorul și mistrețul.

Au fost semnalate specii rare, incluse în cartea Roșie a Moldovei: 8 specii de amfibieni, 3 specii de reptile, 4 specii de păsări, 10 specii de mamifere. Prezența unor specii rare în zonă, cum sunt $P$. fuscus, $C$. austriaca, Hieraaetus pennatus, Felis silvestris, Martes martes a fost semnalată și în cercetările anterioare (Andreev et al., 2012). Factorii negativi cum sunt pășunatul excesiv, defrișarea arbuștilor de la lizieră, distrugerea aglomeraţiilor vegetale, braconajul duc la degradarea ecosistemelor naturale și diminuarea diversității faunei.

Rezervația peisagistică Dobrușa cu ecosistemele adiacente de luncă, pajiște, bazine acvatice cu vegetație abundentă de stufăriș este de o importanță deosebită în conservarea biodiversității din zona de nord a republicii, iar cercetările vor fi continuate.

Studiile au fost efectuate în cadrul proiectelor 11.817.08.13F și 15.187.0211F. 